\title{
Okul öncesi eğitimde öğretmen adayları ve çocukların diyaloglar1
}

\section{Teacher candidates and children's dialogues in preschool education}

\section{Makale Geçmişi \\ Geliş :24 Nisan 2020 \\ Düzeltme :14 Nisan 2021 \\ Kabul : :17 Nisan 2021}

\section{Makale Türü}

Araştırma Makalesi

\section{Article History}

Received :24 April 2020

Revised :14 April 2021

Accepted :17 April 2021

\section{Article Type}

Research Article

\author{
Serap Demiriz ${ }^{1}$, Mehmet Başaran²,
}

Öz: Bu araştırmanın amacı okul öncesi öğretmen adayları ile okul öncesi eğitimine devam eden çocukların diyaloglarını incelemektir. Bu kapsamda öğretmen adayları ve çocukların etkinlik öncesi ve sonrası kullandıkları soru türleri, konuşma araçlarına göre kullandıkları soru türleri ve öğretmenlerin çocukların cevaplarına verdiği geri bildirimler ele alınmıștır. Araștırma nitel desende durum çalıșması olarak tasarlanmıştır. Araştırmaya 71 okul öncesi eğitime devam eden çocuk ve sekiz öğretmen adayı katılmıștır. Araştırma kapsamında etkinlik öncesi ve sonrası çember zamanlarında gerçekleșen öğretmen adayları ve çocukların karşılıklı diyalogları veri olarak kullanılmışır. Bu veriler içerik analizi ile analiz edilmiştir. Araştırmada öğretmen adaylarının genellikle soru sorucu (özellikle kapalı sorular), çocukların ise cevaplayıcı olduğu sonucuna varılmıştır. Elde edilen sonuçlar, çocuk merkezli eğitim ve sorgulama temelli eğitim kapsamında tartışılmıstır. Son olarak ortaya çıkan sonuçlara dayalı olarak araştırmacı ve uygulamacilara önerilerde bulunulmuştur.

Anahtar Kelimeler: Okul Öncesi, Öğretmen-Çocuk Etkileşimi, Diyalog

Abstract: The aim of this research is to examine the dialogues of teacher candidates and children in preschool education. In this context, the types of questions used by pre-service teachers and children before and after the activity, the types of questions they use according to the speaking tools, and the feedbacks given by the teachers to the children's answers were examined. The research is designed as a case study. 71 pre-school children and eight pre-service teachers participated in the study. Within the scope of the research, pre-and post- activity dialogues of pre-service teachers and children were used as data. These data were analyzed by content analysis. In the study, it was concluded that teachers are generally questioner (especially closed questions) and children are respondent. The results are discussed within the scope of the child-centered education and inquiry-based education. Based on the most recent results, suggestions were made to researchers and practitioners.

Keywords: Preschool Education, Teacher-Child Interaction, Dialogue 


\section{SUMMARY}

\section{Introduction}

Preschool education is the most important environment for the development and education of children. For children, one of the most basic elements of this new environment is the teacher. In preschool education, children interact with their teachers in various contexts. One of these contexts in which teacher-child interactions occur is the dialogue in which teachers and children actively participate in the process. These dialogues can be made during the activities as well as during the start and end times of the activities. During these time periods, teachers and children talk about the things to be done that day or evaluate what is done at the end of the activity and day. Accordingly, in the present study, it was aimed to examine the dialogues before or after the activity where the interactions of teachers and children take place verbally. Questions addressed for the purpose of the research are: How is the distribution of the types of questions used by teachers in dialogues according to pre-activity and after-activity?. How is the distribution of the types of questions used by teachers in dialogues by speaking tools?. How is the distribution of the types of questions used by children in dialogues according to pre-activity and after-activity?. How is the distribution of the types of questions used by children in dialogues by speaking tools?, How is the distribution of teachers' feedback on the answers given by the children in the dialogues?

\section{Method}

In this study, one of the methods of qualitative approach, case study method was preferred and porpuseful sampling method was used in the selection of the study group of this research. The research was carried out with 71 children in a public school in Ankara and 8 teacher candidates from the pre-school education department. The data of this research were obtained from the pre-event and post-event times by means of sound recordings. Content analysis was used in the analysis of the data obtained.

\section{Results}

There are three conclusions about the question types used by teachers, the first question of the research, before and after the activity. The first is that teachers use closed questions more than other types of questions in both time periods. The second is that after the activity, the type of question based on expansion has increased slightly. Thirdly, teachers asked open-ended questions about expansion and evaluation in both time periods. Regarding the types of questions used in the speech tools preferred by teachers; it was seen that teachers prefer speaking without tools. In conversations without tools, teachers continued the dialogues with questions and answers. In these dialogues, the teachers asked the most closed-ended questions and the least asked to expand. In conversations using tools, teachers benefited closely from presentations, paintings, objects and puppets. While teachers mostly used closed-ended questions in the dialogues they used for presentations, pictures and puppets, they asked the most expansion-based questions in the dialogs where they preferred the objects. In the third question of the research on the distribution of children's questions 
according to before and after the activity, two results emerged. The first result is that children ask very few questions in the dialogues. The second result is that children prefer the most closed questions such as the findings obtained from teachers before and after the activity. The fourth result of the study, which is related to the use of speech tools of children, is that children ask more questions in the dialogues with the most presentations. The final result in the research is related to the distribution of teachers' feedback to children. Most of the feedback that teachers give to children's answers is related to children's response.

\section{Conclusion and Discussion}

When the questions of the teachers were evaluated in general, it was found that the teachers were more dominant in the dialogue process and asked questions to reveal the information. It is seen that this approach is not suitable for the constructivist approach with the child-centered approach that is effective in today's pre-school education program. The fact that children ask very few questions in the dialogues does not match their level of development. Five-six year old children are in the second phase of the pre-procedure period and approach information intuitively. Accordingly, they frequently use why and how questions. These results may indicate that teachers do not adopt a child-centered and inquiry based dialogue approach. Studies show that interesting and process-oriented activities that stimulate children's curiosity contribute to children's questioning skills. Teachers' feedback on children's answers is mostly related to children's response. This result confirms the question-answer-feedback format of the dialogues. In accordance with the results of the research, the following suggestions can be made. 1.Preparing for dialogues to teachers as they do in other educational processes may increase the quality of the dialogues. 2.Teachers need to include interesting content related to real life that will develop children's curiosity. 3.In this study, teacher candidates' dialogues with children were limited to the data obtained from the slices when they were collective. In this respect, the dialogues of children with teacher-teacher candidates can be examined during the activity processes. Dialogues can also be handled by classifying them according to their types of activity. 4.This research and similar research results can be shared with teachers, and individual and group discussions can be held about their causes and things to be done. 


\section{GİRİ̧̧}

Okul öncesi eğitim aile yaşantısından sonra çocukların gelişimi ve eğitimi açısından en önemli ortamlardan biridir. Çocuklar açısından bu yeni ortamın en temel ögelerinden biri öğretmendir. Okul öncesi eğitiminde çocuklar çeşitli bağlamlarda öğretmenleriyle etkileşimdedirler. Öğretmen ve çocuk etkileşimlerinin oluştuğu bu bağlamlardan biri de eğitim programı çerçevesinde öğretmen ve çocukların sürece aktif olarak katıldığı diyaloglardır (de Vocht, 2015; Seifert, 1969). Bu diyaloglar etkinlik sürecinde olabildiği gibi etkinliklere başlama ve bitiş zamanlarında da özellikle yapılmaktadır. Bu zaman dilimlerinde öğretmen ve çocuklar selamlaşmakta, günlük yaşantılar hakkında sohbet etmekte ve özellikle eğitimsel açıdan o gün yapılacaklara ilişkin konuşmakta veya etkinlik-gün sonunda yapılanları değerlendirmektedirler. Bu doğrultuda mevcut araştırmada, öğretmen adayları ve çocukların etkileşimlerinin sözel anlamda gerçekleştiği etkinlik süreci öncesi ve sonrası yapılan diyalogların nitel olarak incelenmesi amaçlanmışır. Çocukların ve eğitimcilerin birbiriyle olan etkileşimlerinin sınıf ortamında ve ifade edilen zaman dilimlerinde incelenmesi çocukların gelişimine ve eğitimine özgü erken çocukluk eğitimi politikalarının geliştirilmesine katkı sağlayabilir. Bu kapsamda müdahale çalışmalarının oluşturulması eğitimcilerin çocuklarla nitelikli etkileşimleri arttırabilir, çocukların merakını ve keşfetme duygusunu hareketlendirerek dil ve bilişsel gelişimlerine destekleyici diyaloglarda bulunmasına katkı sağlayabilir.

\section{Öğretmen Çocuk Etkileşimi}

Öğretmen çocuk etkileşimi ve bu etkileşimin kalitesi öğretmenin ve çocuğun özellikleri ile etkileşimin meydana geldiği bağlamın türüne göre değişebilmektedir (Whittaker, Williford, Carter, Vitiello ve Hatfield, 2018). Pianta ve arkadaşları (2005) tarafından yapılan araştırmada özellikle dört y1l ve üzerinde tecrübeye sahip öğretmenlerin sınıf etkileşimlerinin daha az tecrübeli öğretmenlere göre daha nitelikli olduğu bulunmuştur. Tecrübeye dayalı olarak ortaya çıkan bu olumlu öğretmençocuk etkileşimleri çocukların okul hazırbulunuşluğunu sağlaması açısından da önemlidir (Heller ve diğerleri, 2012). Bununla beraber öğretmenlik mesleğine yapılan ekonomik yatırımda öğretmen çocuk etkileşimini etkileyebilmektedir. Özellikle çocukların dil gelişimi ile öğretmenlerin aldığı ücretler arasında olumlu bir ilişki bulunmuştur (Hu, Zhou, Chen, Fan ve Winsler, 2017). Bu öğretmen değişkenlerine ek olarak çocukların cinsiyetleri, mizaçları da öğretmen-çocuk etkileşimini etkileyebilmektedir. Yapılan gözlemsel bir çalışmada kızların öğretmenlerle erkeklerden daha fazla etkileşimde bulundukları, daha fazla işbirlikçi ve olumlu etkileşime sahip oldukları bulunmuştur (Colwell ve Lindsey, 2003; Graves, Scott ve Howes, 2011). Çocukların mizaçları veya gelişim yeterlilikleri ilgili yapılan bir araştırmada dil gelişimi açısından yeterli olmayan fakat girişimci çocukların öğretmenleriyle daha fazla çatışma yaşadığı görülmüştür. Bununla beraber dil gelişimi 
açısından yetersiz ve utangaç mizaçlı çocukların öğretmenleriyle bağımlı bir etkileşim içinde bulundukları görülmüştür (Moritz-Rudasill, Rimm-Kaufman, Justice ve Pence, 2006).

Öğretmenin-çocuk etkileşimleri çocukların gelişimi ve öğrenmesi açısından önemlidir. Eğitim alanında yapılan çalışmalarda öğretmen çocuk etkileşimlerinin çocukların okuma-yazma (Hu, Wu, Curby, Wu ve Zhang, 2018), matematik becerilerini arttırdığ1 (Trawick-Smith, Swaminathan ve Liu, 2016), okula hazır bulunuşluğu sağladığ1 (Goble ve Pianta, 2017; Hamre, Hatfield, Pianta ve Jamil, 2014) ortaya konulmuştur. Ayrıca bu etkileşimlerin çocukların akademik başarıları (Van Craeyevelt, Verschueren, Vancraeyveldt, Wouters ve Colpin, 2017) ve sınıf içi olumlu davranışlarıyla da ilişkili olduğu bulunmuştur (Lippard, La Paro, Rouse ve Crosby, 2018). Yapılan boylamsal araştırmalarla da etkileşimlerin bir yıl sonra çocukların sınıf içi olumlu davranışlarını (Lippard ve diğerleri, 2018), dört yıl sonra da çocukların sosyal duygusal uyumunu açılamaya devam ettiği tespit edilmiştir (Wang, Hatzigianni, Shahaeian, Murray ve Harrison, 2016). Özellikle etkileşimin nitelikli olmas1 küçük çocukların okuryazarlığı, dili ve sosyal gelişimindeki kazanımları benzersiz bir şekilde öngörerek, düşük ve yüksek riskli çocuklar arasındaki performanstaki boşlukları kapatmaya katkıda bulunmaktadır (Downer, Sabol ve Bridget, 2010; Hamre ve diğerleri, 2012). Çocuğun gelişim alanlarına yönelik yapılan araştırmalarda ise öğretmen çocuk etkileşiminin çocukların özellikle bilişsel ve sosyal gelişim alanlarıyla ilişkisi incelenmiştir. Öğretmen çocuk etkileşimleri çocukların öğrenmelerinin temelini oluşturan bilişsel gelişimine katkı sağlayabilmektedir. Etkileşimlerin niteliği arttıkça çocukların kavrayış gücü ve bilişsel esnekliği artmaktadır (Hu ve diğerleri, 2017). Alan yazında öğretmen çocuk etkileşimleri çocukların sosyal-duygusal gelişimi açısından da ele alınmıştır. Yapılan bir araştırmada etkileşimlerin niteliğinin çocuğun dışsallaştırma davranışları ile ilişkili olduğu bulunmuştur (Williford ve diğerleri, 2017). Öğretmen ve çocuklar arasında nitelikli etkileşimin meydana gelmesi çocukların dürtüsellik, hiperaktivite, uyumsuzluk ve saldırganlık gibi olumsuz davranışlarını azaltmaktadır (Wang, Brinkworth ve Eccles, 2013; Wang ve diğerleri, 2016). Öğretmen çocuk etkileşiminin süresi ve içeriğine ilişkin nitelikler de çocukların öz ve akran algılarını etkilemektedir. Özellikle niteliğin fazla olması sosyalleşmeye ilişkin olumlu bir algının oluşmasına katkı sağlamaktadır (Colwell ve Lindsey, 2003). Buna karşın azda olsa çalışmalarda öğretmen çocuk etkileşimi ile çocukların sosyal becerileri ile problem davranışları arasında bir ilişkinin olmadığı da tespit edilmiştir (Hu ve diğerleri, 2017). Bu bağlamda çocuklar açısından önemli çıktıları olan eğitimci çocuk etkileşimlerinin diyalog gibi farklı bağlamalrda incelemek önemlidir.

Eğitimci çocuk etkileşimleri güne başlama, fen, matematik, sanat gibi etkinlik zamanlarında; serbest zamanlarda; kahvaltı ve yemek zamanları gibi çeşitli zaman dilimlerinde meydana gelebilmektedir. $\mathrm{Bu}$ zaman dilimlerinden biri de öğretmen ve çocukların bir arada olduğu diyalog zamanlarıdır. 
Diyaloglar öğretmen ve çocukların davranışlarından ziyade konuşmalarını kapsar. Bu etkileşimler serbest zaman dilimlerinden planlanmış etkinlik süreçlerine, güne başlama zamanlarından günü değerlendirme zamanlarına kadar olan süreçlerde bireysel veya grup halinde meydana gelebilmektedir (Bereiter ve Engelmann, 1966; Seifert, 1969).

\section{Öğretmen Çocuk Etkileşiminde Diyaloglar}

Öğretmen-çocuk ilişkileri, öğretmenler ve sınıflarındaki çocuklar arasında zamanla gelişen ve devam eden bağlantıları ifade etmektedir (Lippard ve diğerleri, 2018). Bu ilişkiler, öğretmen-çocuk arasındaki diyaloğu mümkün kılan ve karşlıklı anlayışlara yönelmiş, iş birliğine dayalı eylemler olarak ortaya çıkmaktadır (Emilson ve Johansson, 2009). Diyaloglar alan yazında keşifsel konuşma, işbirlikçi akıl yürütme, diyalog öğretimi, diyalog eğitimi, diyalog pedagojisi, diyalog sorgusu gibi çeşitli şekillerde isimlendirilmiştir. Bu kavramlar odaklarına göre farklılık gösterse de, hepsi diyalog ve etkileşimin bilgiyi nasıl oluşturduğunu ve öğrenmeyi desteklemek için nasıl kullanıldığını tanımlamaktadır (Calcagni ve Lago, 2018; Muhonen, Pakarinen, Lerkkanen, Barza ve Von Suchodoletz, 2018). Bu araştırmada ise yaygın kullanımından dolayı diyalog kelimesi tercih edilmiştir.

Diyaloglar yoluyla öğretmenler, çocukları sınıf tartışmasına dâhil ederek onlara soru sorma, akıl yürütme, değerlendirme ve kendi insiyatiflerini uygulama firsatı sunarlar. Öğretmenler, çocukların katılımı için açı uçlu sorular sorma, geri bildirimler verme gibi çeşitli iskele kurma stratejileri aracıllğıyla çocuklarla ortak anlayış geliştirir, çocukları kendi düşüncelerini açıklamaya teşvik eder ve yeni firsatlar yaratırlar (Gillies, 2013). Bununla beraber yapılan araştırmalar, öğretmenlerin bu stratejileri sınıf ortamında uygulama konusunda genellikle yetersiz kaldıklarını göstermektedir (Webb ve diğerleri, 2009). Öğretmen ve çocuklar arasındaki en yaygın diyalogsal etkileşim biçimi, öğretmenin kısa bir soru sorduğu, bir çocuğun cevapladığ1 ve öğretmenin cevaba ilişkin değerlendirme veya geri bildirim verdiği başlangıç-cevap-geri bildirim biçimidir. Fakat bu başlangıçcevap-geri bildirim yöntemi öğretmenler tarafindan sıkça kullanılmasına rağmen, gerçek ve olması gereken eğitsel diyalog kriterlerini karşılamamaktadır (Howe ve Abedin, 2013).

Okul öncesi eğitim ortamlarında etkili iletişim için açık yönerge ve programlarla desteklenmiş, hassas ve sıcak etkileşimler içeren, duyarlı geri bildirim ve sözlü katılımı sağlayan bir bağlama ihtiyaç duyulmaktadır (Downer ve diğerleri, 2010). Bununla beraber öğretmen-çocuk diyaloglarını inceleyen araştırmaların odağı genellikle konuşma kalıplarıdır. Ancak diyaloglarda göz ardı edilmemesi gereken diğer birçok değişken vardır. Destekleyici bir sınıf atmosferinin önemi, diyalog ve etkinlik sürecinde kullanılan yöntemin uyumu, diyalogla uyumlu bilgi ve öğrenme hedefleri 
hakkındaki anlayışların da dikkate alınması gerekmektedir (Lefstein, Snell ve İsraeli, 2015). Özellikle okul öncesi dönem çocukların bilişsel olarak işlem öncesi dönemde bulunmaları dolayısıyla diyaloglarda konuşma araçlarının kullanılması çocukların diyaloglara bağlı kalması ve süreci takip etmesi açısından önemlidir. Konuşma araçları, sınıfta sözlü etkileşimi şekillendirmek için öğretmenler tarafindan planlı olarak, sistematik ve esnek bir şekilde kullanılabilecek fotoğraf, resim, obje gibi materyallerdir (Calcagni ve Lago, 2018). Bu araçlar etkinlik sürecinin hatırlanması, diyalog sürecini kolaylaştırması, akademik amaçlarla bağlantıların kurulması açısından önemlidir (Sohmer, Michaels, O'Connor ve Resnick, 2009). Etkinlik sürecinin müzede geçirildiği bir günde etkinlik sonu değerlendirmesinin müzede çekilen fotoğrafların çocuklara gösterilerek yapılması konuşma araçlarının kullanımına örnek verilebilir.

Alanyazında diyaloglar; öğretmen ve çocukların sordukları sorular ve öğretmenlerin çocuklara verdikleri geri bildirimler şeklinde incelenmiştir (Bayraktar ve Yalçın, 2019; Howe ve Abedin, 2013). Öğretmelerin sorularının sınıflandırılması Bloom'un bilişsel alan taksonomisindeki bilgi, kavrama, uygulama, analiz, sentez ve yaratıc1lı (Bayraktar ve Yalçın, 2019), betimleyici veya çıkarımsal (Zucker, Justice, Piasta ve Kaderavek, 2010) açık uçlu veya kapalı olma (Bayraktar ve Yalçın, 2019) ve kapalı, açık uçlu, genişletme ve değerlendirme (Işıklığlu-Erdoğan ve Akay, 2015) şeklinde kategorize edilmiştir. Öğretmenlerin çocuklara geri bildirimi de özellikle öğrenmeyi destekleme konusundaki olumlu katkısı nedeniyle sınıf ortamlarında incelenmektedir (Coll, Rochera ve de Gispert, 2014). Öğretmenlerin geri bildirimleri yazıll veya sözlü şekilde olabilmektedir (Mahfoodh, 2017). Okul öncesi öğretmenleri genellikle sözlü geri bildirimleri tercih etmektedir. Alanyazında bu bildirimler genel veya özel (Fletcher, 1993), olumlu veya olumsuz (Bayraktar ve Yalçın, 2019), kabul etme veya reddetme (Quinton ve Smallbone, 2010) ile yansitıcı olarak ifade edip etmeme (Mahfoodh, 2017) olarak sınıflandırılmıştır. Ayrıca geri bildirimlerle ilgili öğretmenlerle yapılan durum çalışmasında öğretmenler geri bildirimi; öğrenme bağlamı, akademik ödev ve sosyal katılım olarak da sınıflandırmıştır (Coll ve diğerleri, 2014). Bununla beraber geri bildirim esnasında öğretmenlerin çocukları bekleme süreleri de bir değişken olarak ele alınmıştır (Bayraktar ve Yalçın, 2019). Öğretmen çocuk diyaloglarında çocukların soruları da yine Bloom'un bilişsel alan taksonomisine göre (Bayraktar ve Yalçın, 2019) cevapları ise amaca uygunluk, serilik, üretkenlik ve orjinallik (Yıldız, Demiriz ve Ulutaş, 2018), kelime dağarcığının darlığı veya genişliği (Zucker ve diğerleri, 2010) cümle yapılarının kısalığ1 veya uzunluğu (Warren-Leubecker ve Bohannon, 1983) şeklinde sınıflandırıldığı görülmüştür. 


\section{Problem Durumu}

Alan yazında var olan öğretmen-çocuk diyaloglarına ilişkin araştırmaların çoğunluğu çocuklardan çok öğretmenlerin görüş ve algısını yansıtmaktadır (Coll vd. 2014; Hamre and Pianta 2001; Mahfoodh, 2017). Bu araştırmada diyaloglarda hem öğretmen adaylarının hem de çocukların ifadeleri ele alınmıştır. Öğretmen çocuk diyaloglarının ses kayıtları gibi farklı yöntemler kullanılarak incelenmesi alanyazını zenginleştirebilmektedir (Lippard ve diğerleri, 2018). Öğretmen çocuk diyalogları hem bireysel hem de grup halinde incelenebilmektedir (Colwell ve Lindsey, 2003). Bu araştırmada bulgular öğretmen adayları-çocuk grup diyaloglarından elde edilmiştir. Alanyazında öğretmen çocuk diyaloglarının oyun zamanlarında (Trawick-Smith ve diğerleri, 2016; Van Craeyevelt ve diğerleri, 2017), günün başlangıcından öğleye kadar olan zaman diliminde (Hu ve diğerleri, 2017), serbest zaman ve öğretmen yönelimli aktiviteler zamanında (Goble, ve Pianta, 2017) incelendiği tespit edilmiştir. Bununla beraber öğretmen çocuk diyalogları hakkındaki alan yazının genellikle Amerika ve Avrupa gibi batı ülkeleri ekseninde şekillendiği görülmektedir (Muhonen ve diğerleri, 2018). Alan yazın incelendiğinde Türkiye'de öğretmen adaylarıyla çocuk diyaloglarının incelendiği araştırmalara da ihtiyaç duyulduğu görülmüştür. Özellikle mesleğe başlang1ç düzeyinde olan öğretmen adaylanının mesleki anlamda desteklenmeleri ve bu bağlamda lisans programlarının güçlendirilmesine katkı sağlaması açısından durum tespitlerinin yapılması önemlidir. Bu doğrultuda bu araştırmanın temel amacını okul öncesinde öğretmen adayları ile çocukların diyaloglarının ses kayıtları aracılığıyla incelenmesi oluşturmuştur. Araştırmanın amacına uygun olarak ele alınan sorular şunlardır:

1. Öğretmen adaylarının etkinlik öncesi ve etkinlik sonrasında diyaloglarda kullandıkları soru türleri nelerdir?

2. Öğretmen adaylarının konuşma araçlarına göre diyaloglarda kullandıkları soru türleri nelerdir?

3. Çocukların etkinlik öncesi ve etkinlik sonrasında diyaloglarda kullandıkları soru türleri nelerdir?

4. Çocukların konuşma araçlarına göre diyaloglarda kullandıkları soru türleri nelerdir?

5. Diyaloglarda çocukların verdikleri cevaplara göre öğretmen adaylarının ifadeleri nelerdir?

\section{YÖNTEM}

$\mathrm{Bu}$ araştırma nitel desende tasarlanmıştır. Nitel desende araştırmalar, grupların veya bireylerin bir probleme atfettikleri anlamları keşfetmeye ve anlamaya dayalı bir yaklaşımla yürütülmektedir (Tashakkori ve Creswell, 2007). Bu araştırmada nitel yaklaşımın yöntemlerinden biri olan durum 
çalışması yöntemi tercih edilmiştir. Durum çalışması belli bir bağlam içerisinde gerçekleşen durumlarla ve bu durumları deneyimleyen bireylerle ilgili derinlemesine bilgi sağlayan bir yöntemdir (Creswell ve Clark, 2007). Bu yöntemin amacı elde edilen bulguları genellemekten ziyade incelenen durumlar veya bireylerle ilgili zengin bulguların elde edilmesine olanak tanımaktır (Aytaçlı, 2012). $\mathrm{Bu}$ araştırmanın amacı öğretmen adaylarının ve çocukların günün belli zamanlarında beraber yaptıkları toplu diyalogları incelemek olduğundan nitel araştırmalardan durum çalışması yöntemi kullanılmıştır.

\section{Çalışma Grubu}

$\mathrm{Bu}$ araştırmanın çalışma grubunun seçiminde uygun örnekleme yöntemi esas alınmıştır. Bu yöntem çalışmanın bağlamına göre evren ve örneklem grubunun tasarlanması ve araştırmanın belirlenen örneklemle yürütülmesinin mümkün olmadığ1 durumlarda araştırmacılara zaman ve pratiklik kazandırmaktadır (Özen ve Gül, 2007). Bu doğrultuda araştırmanın çalışma grubunu Ankara il merkezinde bulunan resmi bir okul öncesi eğitim kurumunda öğretmenlik uygulaması yapmakta olan gönüllü öğretmen adayları ve çocuklarla gerçekleştirilmiştir. Araştırmaya katılan öğretmen adayları okul öncesi öğretmenliği lisans dördüncü sınıfta öğrenimlerine devam etmektedir. Öğretmen adaylarından biri erkek ve diğer yedisi ise kız öğrencidir. Çalışmaya anaokuldaki iki ayrı sınıftan toplam 71 çocuk katılmıştır. Okul öncesi eğitime devam eden 60-72 aylık çocukların cinsiyetleri, kardeş sayıları ve ebeveynlerinin çalışma durumuna ilişkin demografik bilgileri Tablo 1'de gösterilmektedir.

Tablo 1: Çalışma grubunun özellikleri

\begin{tabular}{|c|c|c|c|}
\hline \multicolumn{2}{|c|}{ Demografik değişkenler } & $\mathrm{f}$ & $\%$ \\
\hline \multirow{2}{*}{ Çocukların cinsiyeti } & $\mathrm{K}_{1 z}$ & 34 & 48 \\
\hline & Erkek & 37 & 52 \\
\hline \multirow{4}{*}{ Kardeş sayısı } & Tek çocuk & 36 & 51 \\
\hline & Bir kardeş & 17 & 24 \\
\hline & İki kardeş & 13 & 18 \\
\hline & Üç kardeş ve üzeri & 5 & 7 \\
\hline \multirow{2}{*}{ Annenin çalışma durumu } & Evet & 60 & 85 \\
\hline & Hayır & 11 & 15 \\
\hline \multirow{2}{*}{ Babanın çalışma durumu } & Evet & 69 & 97 \\
\hline & Hayır & 2 & 3 \\
\hline Toplam & & 71 & 100 \\
\hline
\end{tabular}

Tablo 1'de, çocukların \%52'sinin erkek, \%48'inin kız olduğu; çocukların \%51'inn ailenin tek çocuğu olduğu; annelerin \%85’inin, babaların ise \%97’sinin çalıștığı görülmektedir. 


\section{Veri Toplama ve Analiz}

Nitel araştırmalarda verilerin toplanmasında görüşme, görüşme formları, video kayıtları, odak grup görüşmeleri, gözlem kayıtları gibi birçok yöntem kullanılmaktadır. Bu araştırmanın verileri ses kayıtları aracılığıyla elde edilmiştir. Öncelikle araştırma kapsamında ses kayıtlarının yapılacağı zaman dilimleri belirlenmiştir. Araştırmanın amacına uygun olarak sesler 2019 yılının güz döneminde öğretmen adaylarının ve çocukların toplu bir şekilde diyaloga geçtikleri etkinlik öncesi ve sonrası çember zamanlarında araştırmacılar ve gönüllü öğretmen adayları tarafından kaydedilmiştir. Sınıftaki tüm seslerin net alınması amacıyla dört kayıt cihazı kullanılmıştır. Ses kayıt cihazının sınıf ortamındaki seslere duyarlı olmasına ve kayıt esnasında çocukların dikkatini dağıtmayacak şekilde göz önünde olmamasına özen gösterilmiştir. Okul öncesi eğitiminde ilk haftalar çocukların ve öğretmen adaylarının okula ve birbirlerine uyum sağlaması söz konusu olduğundan vriler dördüncü haftadan itibaren elde edilmeye başlanmış ve haftada bir gün olmak üzere toplam sekiz haftada toplanmıştır. Ses kayıtlarının alınması için eğitimcilerin, çocukların ve ailerin onamları alınmıştır. Bu kapsamda anne babalardan çocuğun demografik bilgileri alınmış ve bu süreçte araştırma hakkında bilgilendirmeler yapılmıştır. Çalışmaya gönüllü katılan öğretmen adaylarının doğal tutum ve davranışlarını değiştirmemeleri amacıyla ses kayıtlarından elde edilen verilerin bilimsel amaçla analiz edileceği, araştırma sonuçlarının kendileriyle paylaşılacağı ifade edilmiş, detaylar hakkında bilgi verilmemiştir. Çünkü öğretmen adaylarının detaylar hakkında bilgilendirilmeleri araştırmanın bulgularını olumsuz etkileyebilmektedir. Bilimsel çalışmalarda araştırmacılara zarar vermeyen durumlarda bu yola başvurulabilinmektedir (Santrock, 2010, s.38). Bu durumla bağlantılı olarak elde edilen verilerin katılımcılarla paylaşılması da etik açıdan önem arz etmektedir (Santrock, 2010, s.38). $\mathrm{Bu}$ doğrultuda daha sonra öğretmen adaylarıyla yapılan görüşmelerde araştırmanın bulguları paylaşılmıştır.

Ses kayıtlarının yazıya aktarılması araştırmacılar ve diyalog sürecine katılan gönüllü öğretmen adayları tarafından seslerin kaydedildiği günde birlikte yapılmıştır. Bu stratejiye araştırmanın veri kaybını en aza indirmek amacıyla başvurulmuştur. Yazıya geçirilen ses kayıtları araştırmacılar tarafından daha sonra tekrar tekrar dinlenerek eksik ve hata olmaması açısından kontrol edilmiştir. Araştırma kapsamında incelenen ses kayıtlanına ilişkin bilgiler Tablo 2'de gösterilmiştir. 
Tablo 2. İncelenen ses kayıtlarına ilişkin veriler

\begin{tabular}{lccc}
\hline & $\mathbf{n}$ & $\mathbf{s}$ & $\mathbf{x}$ \\
\hline Etkinlik öncesi & 20 & $117.1 \mathrm{dk}$ & 6.16 \\
\hline Etkinlik sonras1 & 16 & $148.53 \mathrm{dk}$ & 10.60 \\
\hline Toplam & 36 & 265.63 & 8.38 \\
\hline
\end{tabular}

n: Toplam oturum sayısı, $\mathbf{s}$ : toplam kaydedilen süre, $\mathbf{x}$ : oturum başına ortalama süre

Tablo 2'de etkinlik öncesi 20, etkinlik sorasında ise 16 oturumdaki diyaloğların kaydedildiği; etkinlik öncesindeki toplam ses kaydı süresinin 117.1 dakika, etkinlik sonrasındaki ise 148.53 dakika olduğu; böylece toplama 36 oturumda 265.63 dakikalık bir ses kaydı üzerinden analizlerin gerçekleştirildiği görülmektedir.

Elde edilen verilerin analizinde içerik analizi kullanılmıștır. İçerik analizi tümden gelimsel ve tümevarımsal olmak üzere iki şekilde yapılabilmektedir (Glesne, 2013). Bu araştırmada her ikisi de kullanılmıştır. Tümden gelimsel içerik analizinde veriler alan yazında var olan kategorilere göre analiz edilmektedir. Bu araştırma kapsamında öğretmen adaylarının ve çocukların kullandıkları soru türlerinin kategorileştirilmesinde Bloom’un soru sınıflandırılması kullanılmıştır. Bloom’a göre dört soru türü şunlardır: kapalı uçlu, açık uçlu, genişletmeye dayalı ve değerlendirmeye dayalı sorulardır (Bay ve Alisinanoğlu, 2012; Işıklığlu-Erdoğan ve Akay, 2015). Öğretmen adaylarının çocuklara yönelik veri geri bildirimleri ise tümevarımsal içerik analizi ile analiz edilmiştir. Bu doğrultuda veriler tekrar-tekrar okunarak ve araştırmacılar arasında fikir alışverişi sağlanarak kategoriler belirlenmiştir. Oluşturulan bu kategorilere ilişkin uzman görüşü alınarak son şekli verilmiştir.

Nitel araştırmalarda verilerin geçerliliği çeşitli kriterler yerine getirilerek sağlanabilir. Bu kriterler inanırlık, onaylanabilirlik ve aktarılabilirliktir (Başkale, 2016; Yıldırım ve Şimşek, 2013, s.306). İnanırlık verilerin doğal olarak elde edilmesini sağlamak amacıyla çalışma grubuyla etkileşimin yeterli düzeyde olmasını gerektirir. Bu kriterin sağlanması amacıyla veriler çocukların eğitim gördükleri sınıf içerisinde toplanmıștır. Onaylanabilirlik açısından ses kayıtları oluşturulduktan sonra yukarıda ifade edilen yazıya geçirilme ve kodlama aşamaları araştırmacıların işbirliği içerisinde yapılmış ve bulguların kodlanması esnasında ham veriler tekrar-tekrar incelenmeye alınmıştır. Ayrıca onaylanabilirliğin arttırılması için bulgular kısmında katılımcı ifadelerine de sıklıkla yer verilmiştir. Anonimliği sağlamak için öğretmen adayları Ö1, Ö2, Ö3... şeklinde çocuklar ise Ç1, Ç2, Ç3... şeklinde kodlanmıştır. Nitel araştırmalarda genelleştirme amacı yani aktarılabilirlik şartının yerine getirilmesi çok mümkün olmasa da özellikle araştırmanın bağlamının ve katılımcıların özelliklerinin detaylı olarak ifade edilmesi, araştırma sürecinin tüm süreçlerinin açık bir şekilde belirtilmesiyle sağlanabilir. Verilerin güvenilirliğinin hesaplanmasında ise Miles ve Huberman'ın önerdiği yöntem kullanılmıştır. Bu yönteme göre kodlayıcılar arasındaki uyumun \%70 üzerinde 
olması gerekmektedir (Miles ve Huberman, 1994, s.64). Bu açıdan verilerin \%20’lik bir kısmı farklı bir araştırmacı tarafından kodlanmış ve aradaki uyumun kabul edilebilir bir düzeyde olduğu görülmüştür $(\% 83>\% 70)$.

\section{BULGULAR}

$\mathrm{Bu}$ bölümde araştırmanın sorularına paralel olarak elde edilen bulgulara yer verilmiştir. $\mathrm{Bu}$ kapsamda sırasıyla önce öğretmenlerin (Tablo 3, Tablo 4) daha sonra çocukların (Tablo 5, Tablo 6) diyaloglarda kullandıkları soru türleri etkinlik öncesi ve sonrasına göre, kullanılan konuşma araçlarına göre incelenerek son kısımda çocukların verdiği cevaba göre öğretmen adaylarının ifadelerinin dağ 1 lımına yer verilmiştir.

Tablo 3. Öğretmen adaylarının etkinlik öncesi ve etkinlik sonrasında kullandıkları soru türlerinin frekanslarına göre dağılımı

\begin{tabular}{cccccc}
\hline Kategori & Kapalı & Açık uçlu & Genişletme & Değerlendirme & n \\
\hline Etkinlik öncesi & 103 & 54 & 25 & 17 & 199 \\
\hline Etkinlik sonrası & 107 & 23 & 36 & 21 & 187 \\
\hline Toplam & 210 & 77 & 61 & 38 & 386 \\
\hline
\end{tabular}

Tablo 3 'te öğretmen adaylarının kapalı, açık uçlu, genişletme ve değerlendirmeye yönelik sordukları sorularının frekansının sırasıyla etkinlik öncesinde 103, 54, 25, 17; etkinlik sonrasında ise sırasıyla 107, 23, 36, 21 olduğu görülmektedir. Etkinlik öncesinde en çok kullanılan soru türünün kapalı sorular olduğu bunları açık uçlu, genişletme ve değerlendirmeye yönelik soruların takip ettiği görülmektedir. Etkinlik sonrasında ise kapalı soruların en çok kullanılan sorular olduğu bu soruları ise genişletme, açık uçlu ve değerlendirmeye yönelik soruların takip ettiği görülmektedir. Hem etkinlik öncesi hem de etkinlik sonrasında en çok kullanılan soru türü kapalı, en az kullanılan soru türü ise değerlendirmeye yönelik sorulardır. Etkinlik öncesinde öğretmen adaylarının kullandığ1 kapalı, açık uçlu, genişletme ve değerlendirmeye yönelik sorulara ilişkin örnekler sırasıyla şu şekildedir:

Kapalı: "Hayvanat bahçesinde dinožr var mıdır?" (Ö1).

Aç1k uçlu: "Bugün yolda gelirken dikkkatiniẓi çeken neler oldu? ” (Ö5).

Genişletme: “Bu oda nasıl bölle dağını hale geliyor." (Ö2).

Değerlendirme: "Çocuklar ben yürüyerek geliyorum okula gelirken de baž şeyler fark ettim. Baž ağaçlarn yemyeşil olduğunu bąılarmmsa yapraklarmm sarardiğmn gördüm. Neden olmus olabilir siz̨ce? ” (Ö8). 
Etkinlik sonrasında öğretmen adaylarının kullandığı kapalı, açı uçlu, genişletme ve değerlendirmeye yönelik sorulara ilişkin örnekler sırasıyla şu şekildedir:

Kapalı: “Okuduğumuz bikâyede papă̆an bah kimden almıș? ” (Ö3).

Açık uçlu: "Peki, çocuklar kitabı okurken sevdig̈iniz bir kısım oldu mu?" "Baskea sımfimızda a sesi ile başlayan bir şey var mi? "(Ö6).

Genişletme: "Peki, çocuklar bu bikâyede pengueni bir yere koymak isteseydiniz nereye koyardını bu bikâyenin neresinde olmali penguen?" (Ö1).

Değerlendirme: “Gökkuşă̆g gördüğ̈̈nüzde kendiniz̨i nasıl hissediyorsunu₹?” (Ö7)

Araştırmanın ikinci sorusu kapsamında öğretmen adaylarının tercih ettikleri soru türlerinin konuşma aracı kullanma durumuna göre dağılımı Tablo 4’te sunulmuştur.

Tablo 4. Öğretmen adaylarının soru türlerinin konuşma aracı kullanma durumuna göre dağllımı

\begin{tabular}{ccccccc}
\hline Kategori & Alt kategori & Kapalı & Açık uçlu & Genişletme & Değerlendirme & $\mathbf{n}$ \\
\hline \multirow{2}{*}{ Araçsız } & Soru-cevap & 126 & 56 & 16 & 22 & 220 \\
\hline \multirow{3}{*}{ Araçli } & Sunumlarla & 36 & 8 & 5 & 6 & 55 \\
\cline { 2 - 7 } & Resim & 12 & 3 & 4 & 5 & 22 \\
\cline { 2 - 7 } & Obje & 18 & 4 & 33 & 3 & 57 \\
\hline & Kukla & 18 & 6 & 3 & 38 & 386 \\
\hline
\end{tabular}

Tablo 4'te öğretmen adaylarının sorularının diyaloglarda kullanılan konuşma araçlarına göre frekans dağıllımı incelendiğinde sadece soru cevaplarla diyalogların sürdürüldüğg̈ araçsız konuşmalarda en çok kapalı soruların sorulduğu bu soruları açık uçlu, genişletme ve değerlendirmeye yönelik soruların takip ettiği görülmektedir. Öğretmen adaylarının etkinlik öncesi çocuklarla konuşma arac1 olarak sunum veya video ile etkinlik sürecini fotoğraflayıp etkinlik sonunda konuşma aracı olarak kullandığ1 sunumlarla yapılan diyaloglarda en çok kapalı uçlu soruları tercih ettiği, bu soruları sırasıyla açık uçlu, değerlendirme ve genişletmeye dayalı soruları takip ettiği görülmektedir. Konuşma aracı olarak resim kullanılan diyaloglarda öğretmen adaylarının en çok kapalı uçlu soruları kullandığı bunları değerlendirme ve genişletmeye yönelik sorular ile açık uçlu soruların takip ettiği görülmektedir. Konuşma aracı olarak nesnenin kullanıldığı diyaloglarda öğretmen adayları en çok kapalı uçlu soruları kullanmış ve bu soruları ise genişletme açık uçlu ve değerlendirme soruları izlemiştir. Öğretmen adaylarının kuklayı konuşma aracı olarak tercih ettiği diyaloglarda ise en çok 
kapalı uçlu soruların kullanıldığı ve bunları açık uçlu, genişletme ve değerlendirmeye yönelik soruların takip ettiği görülmektedir.

Öğretmen adaylarının herhangi bir konuşma aracı kullanmadan yaptıkları soru-cevaplı diyaloglardaki kapalı, açık uçlu, genişletme ve değerlendirmeye yönelik soru türlerine sırasıyla şu Örnekler verilebilir:

Kapalı: "Kutuplarda insanlar yaşzyor mu?” (Ö8).

Aç1k uçlu: "Su birikintilerini nerelerde görebilirið̨?” (Ö2).

Genişletme: “Sımıfimı̨da bangi nesneler büyük?”” (Ö5).

Değerlendirme: "Siz, Bayan Küt yerinde olsaydmı nasıl hissederdiniæ̨?" (Ö1).

Öğretmen adaylarının video veya fotoğraflar kullandığı diyaloglardaki kapalı, açık uçlu, genişletme ve değerlendirmeye yönelik soru türlerine şu örnekler verilebilir:

Kapal1: “Cocuklar bunlar ne?’ (Ö3)(Fosiller gösterilerek).

Aç1k uçlu: “Siz̧ce tabiat-doğa ne demek?? Ö2) (Tabiat tarihi müzesi gösterilerek).

Genişletme: "Siz̧ce ayakkabı nasıl yapılyyor?" (Ö5) (Ayakkab1 yapımını anlatan bir videonun başlangicinda).

Değerlendirme: "Peki müzedeki esyalara neden dokunmamalyyz Erdem?” (Ö7) (Müzedeki eşyaların fotosu gösterildiğinde).

Öğretmen adaylarının resimler kullandığı diyaloglardaki kapalı, açık uçlu, genişletme ve değerlendirmeye yönelik soru türlerine sırasıyla şu örnekler verilebilir:

Kapalı: "Peki sen tamamladin mi resmini?” (Ö7).

Aç1k uçlu: "Anlatır misin burada ne çizdiğini Kuzey” (Ö2).

Genişletme: "Sen nasıl tamamladın Mona Lisa'yı?” (Ö6).

Değerlendirme: “Neden üggün resim çįdin Mert?” (Ö5). 
Öğretmen adaylarının objeler kullandığı diyaloglardaki kapalı, açık uçlu, genişletme ve değerlendirmeye yönelik soru türlerine sırasıyla şu örnekler verilebilir:

Kapal1: “Senin yaptığmn terlï̈in rengi ne?” (Ö3).

Aç1k uçlu: "Bu ölçme araçlaryla neler ölçebilirsiniæ çocuklar" (Ö2).

Genişletme: "Biž sunlar nasıl ölçerį??” (Ö8).

Değerlendirme: “Terliğine neden şaşkın adın verdin?” (Ö4).

Öğretmen adaylarının kukla kullandığı diyaloglardaki kapalı, açık uçlu, genişletme ve değerlendirmeye yönelik soru türlerine sırasıyla şu örnekler verilebilir:

Kapalı: "Şimdi sizinle beraber bir tekerleme söyleyelim mi?”, (Ö2). "Benim kaç kenarm var?” (Ö5).

Açık uçlu: “Ama bu ne kuklası olabilir siz̨ce?” (Ö7).

Genişletme: "Bu nasıl bir kiv??” (Ö8).

Değerlendirme: "Benim adım neden dikdörtgen olabilir siz̨ce?” (Ö2).

Araştırmanın üçüncü sorusu kapsamında çocukların etkinlik öncesi ve etkinlik sonrasında kullandıkları soru türlerinin frekanslarına göre dağılımı Tablo 5’te sunulmuştur.

Tablo 5. Çocukların etkinlik öncesi ve etkinlik sonrasında kullandıkları soru türlerinin frekanslarına göre dağılımı

\begin{tabular}{cccccc}
\hline Kategori & Kapalı & Açı uçlu & Genişletme & Değerlendirme & $\mathbf{n}$ \\
\hline Etkinlik öncesi & 12 & 3 & 7 & 0 & 22 \\
\hline Etkinlik sonrası & 2 & 0 & 0 & 0 & 2 \\
\hline Toplam & 14 & 3 & 7 & 0 & 24 \\
\hline
\end{tabular}

Tablo 5'te çocukların kapalı, açık uçlu, genişletme yönelik sordukları sorularının frekansının sırasıyla etkinlik öncesinde 12, 3, 7; etkinlik sonrasında ise kapalı sorulardan 2 tane sordukları görülmektedir. Çocukların etkinlik öncesinde değerlendirmeye yönelik etkinlik sonrasında ise açık uçlu, genişletme ve değerlendirmeye yönelik soru türlerinden ise hiç sormadıkları görülmektedir. Etkinlik öncesinde en çok kullanılan soru türünün kapalı sorular olduğu bunları genişletmeye yönelik ve açık uçlu soruların takip ettiği görülmektedir. Etkinlik öncesinde çocukların kullandığı kapalı, açık uçlu ve değerlendirmeye yönelik sorular sırasıyla şu şekilde örneklendirilebilir: 
Kapalı: “Öğretmenim yoksa yangın mı çıtı evde?” (Ç22).

Aç1k uçlu: “Dünyada ki en soğuk yer neresi?’' (Ç15).

Değerlendirme: “Neden ceket giymiyorsun ögretmenim?” (Ç2).

Etkinlik sonrasında çocukların kullandığı kapalı soru ise şu şekilde örneklendirilebilir:

Kapalı: “Öğretmenim 20 ayllk dişin mi çktt??’ (Ç28).

Araştırmanın dördüncü sorusu kapsamında çocukların soru türlerinin konuşma aracı kullanma durumuna göre dağılımı Tablo G’te sunulmuştur.

Tablo 6. Çocukların soru türlerinin konuşma aracı kullanma durumuna göre dağılımı

\begin{tabular}{ccccccc}
\hline Kategori & Alt kategori & Kapalı & Açı uçlu & Genişletme & Değerlendirme & n \\
\hline \multirow{2}{*}{ Araçsız } & Soru-Cevap & 3 & 3 & 1 & 0 & 7 \\
\hline \multirow{3}{*}{ Araçsız } & Sunumlarla & 7 & 0 & 5 & 0 & 12 \\
\cline { 2 - 7 } & Resim & 1 & 0 & 0 & 0 & 0 \\
\cline { 2 - 7 } & Obje & 0 & 0 & 0 & 0 & 4 \\
\cline { 2 - 7 } & Toplam & 14 & 3 & 1 & 0 & 24 \\
\hline
\end{tabular}

Tablo 6'da çocukların konuşma araçlarına göre soru türleri incelendiğinde araçsız konuşmalarda kapalı ve açık uçlu sorulardan 3'er soru, genişletmeye yönelik sorulardan 1 soru; sunumların kullanıldığı diyaloglarda kapalı uçlu 7, genişletmeye yönelik 5 soru; resmin kullanıldığ1 diyaloglarda kapalı uçlu 1 soru; kuklaların kullanıldığı diyaloglarda kapalı uçlu 3 soru, genişletmeye yönelik 1 soru sordukları görülmüştür. Konuşma aracı olarak çeşitli objelerin kullanıldığı konuşmalarda ise çocukların hiç soru sormadıkları görülmüştür. Tüm araçsız diyaloglarda ve konuşma araçlarının kullanıldığı diğer tüm diyaloglarda çocuklar değerlendirmeye yönelik sorular sormamıştır. Konuşma araçlarının kullanıldığı diyaloglarda açık uçlu sorular sormamıştır. Ayrıca genişletmeye yönelik sorular resim ve objenin kullanıldığı diyaloglarda hiç sorulmamış ve kapalı uçlu sorularda materyallerin kullanıldığı diyaloglarda sorulmamıştır. Çocuklanın herhangi bir konuşma aracı kullanılmadan yapılan soru-cevaplı diyaloglardaki kapalı, açık uçlu ve genişletme yönelik soru türlerine sırasıyla şu örnekler verilebilir:

Kapalı: "Pis koktuğu için mi?” (Ç22).

Aç1k uçlu: “Öğretmenim siz̨in en sevdiğiniž renk ne?” (Ç28). 
Genişletme: “Karlar geri nasıl gidiyor?” (Ç6).

Çocukların sunum kullanılarak yapılan diyaloglardaki kapalı ve genişletmeye yönelik soru türlerine sırasıyla şu örnekler verilebilir:

Kapalı: “Ayakkeabrya çivi takıllı mı?” (Ç5).

Genişletme: "Videodaki adam bu ayakkeabı parçalarm nasıl yapıştıracak?’' (Ç17).

Çocukların resim kullanılarak yapılan diyaloglardaki kapalı soru türüne şu örnek verilebilir:

Kapalı: "Önce kenarlarm yaptım. Sonra saçlarm yaptım. Sonra da söyleyeyim m?? (Ç25).

Çocukların kukla kullanılarak yapılan diyaloglardaki kapalı ve genişletme soru türlerine sırasıyla şu örnekler verilebilir:

Kapalı: "Peki yaptrğm ayakkeabr su geçirir mi??' (Ç16).

Genişletme: “Ayakkeabı tasarmmosı nasıl bir şey?’” (Ç8).

Araştırmanın beşinci sorusu kapsamında çocukların verdikleri cevaplara göre öğretmen adaylarının ifadelerinin dağılımı Tablo 7'de sunulmuştur.

Tablo 7. Çocukların verdikleri cevaplara göre öğretmen adaylarının ifadelerinin dağılımı

\begin{tabular}{|c|c|c|c|}
\hline Kategori & Alt kategori & $\mathbf{n}$ & \\
\hline \multirow{3}{*}{$\begin{array}{c}\text { Verilen cevaba yönelik geri } \\
\text { bildirim }\end{array}$} & Onaylama & 94 & \multirow{3}{*}{294} \\
\hline & Farklı bir soru sorma & 92 & \\
\hline & Açılkama & 108 & \\
\hline \multirow{4}{*}{$\begin{array}{l}\text { Verilen cevaptan bağımsız } \\
\text { ifadeler }\end{array}$} & Sınıf yönetimi stratejilerinin kullanılması & 41 & \multirow{3}{*}{180} \\
\hline & Başka bir çocuğa yönelme & 54 & \\
\hline & Bağımsız soru sorma & 85 & \\
\hline & Toplam & & 474 \\
\hline
\end{tabular}

Tablo 7'de öğretmen adaylarının çocukların cevaplarına yönelik geri bildirimleri incelendiğinde 294 geri bildirimin çocukların cevaplarına yönelik bir geri bilidirimi içerdiği, 180 geri bildirimin ise çocukların verdiği cevaplarından bağımsız olduğu görülmektedir. Öğretmen adaylarının çocukların cevaplarına yönelik geri bildirimlerinin sıklık sırasına göre sırasıyla; verilen cevabı açılama (108), onaylama (94) ve cevapla ilgili farklı bir soru sorma (92) alt kategorilerinden oluştuğu görülmektedir. Öğretmen adaylarının çocukların verdiği cevaplardan bağımsız ifadelerinin ise, verilen cevaptan bağımsız soru sorma (85), başka bir çocuğa yönelme (54) ve sınıf yönetimi stratejilerinin 
kullanılması (41) alt kategorilerinden oluştuğu görülmektedir. Cevaba yönelik geri bildirim kategorisinin alt kategorilerin sıklı̆ının birbirine yakın olduğu; cevaptan bağımsız ifadeler kategorisinin alt kategorilerinden, verilen cevaptan bağımsız soru sorma alt kategorisinin, diğer iki kategoriye göre daha sık kullanıldığı görülmektedir. Öğretmen adaylarının çocukların verdiği cevaplara yönelik geri bildirim örnekleri aşağıda sunulmuştur:

Öğretmen adayı çocuklara geçen hafta ne yaptıklarını sormuştur. Bir çocuk “dinozor fosili” diye cevap vermiştir. Öğretmen bu cevabı onaylamaya yönelik olarak "Evet fosilleri çalıșmıstık..." (Ö5) şeklinde çocuğun cevabını tekrarlayarak ve "evet" ifadesini kullanarak geri bildirim vermiştir. (Cevaba yönelik onaylama ifadeleri).

Öğretmen adayı çocuklara sonbaharda neler olduğunu sormuştur. Çocuklar yaprakların döküldüğünü, sarardığını ifade etmiştir. Bunun üzerine öğretmen adayı "peki onlar tekrar çıkacak mı?” (Ö1) şeklinde çocukların cevaplarıyla ilgili farklı bir soru sormuştur. (Cevapla ilgili farklı bir soru sorma).

Öğretmen adayı müze ziyareti sonrası çocuklara çekilen fotoğraflarla ilgili sunumu göstermekte ve fotoğraflar hakkında konuşmaktadırlar. Tabiat Tarihi fotoğrafının olduğu sunumda öğretmen adayı çocuklara "tabiat” kelimesinin ne olduğunu sormuştur. Çocuklardan bir "hayat” cevabını vermiştir. Bunun üzerine öğretmen aday1 "Evet hakhsın hayata benziyor. Yaşadiğımı bu çevre biz̨im tabiatımı. Ve burada çooook eski zamanlarda yaşayan başka canllarda vard. Bu müz̧ çok eski zamanlarda yaşamıs olan canlılarn kahntılarm görmemiæ̧i sağlıyor...” (Ö5) (Verilen cevabı açıklamaya yönelik ifadeler).

Öğretmen adaylarının çocukların verdiği cevaplardan bağımsız geri bildirim örnekleri aşağıda sunulmuştur:

Ö ğretmen adayı diyaloglarda “Gruplardan niye ses geliyor?”, "Siz sandalyeleriniz̨i çekerek, ses çıkaryorsunu₹,

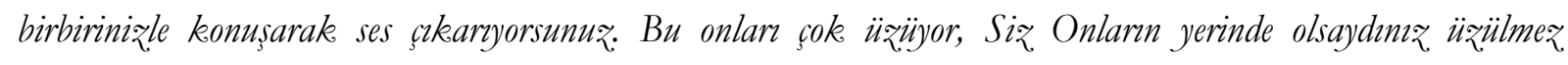
miydiniz̨? Onlar siz̨i dinledi”, "Ben buradan Ayse'yi duyamyyorum Ayse’nin yanında olmama rağmen O'nu duyamyorum, siz, onu nasıl duyabiliyorsunu₹?" (Ö2), "Enes dinleyelim m??” (Ö6) ifadeleriyle çocukların sorduğu soruya cevap vermek ve ya verdiği cevabı yönlendirmek yerine sınıf yönetimine yönelik ifadeler kullanmışlardır. (Sınıf yönetimi stratejilerine ilişkin ifadeler)

Öğretmen aday1 "Evet hava basska neden kirli olabilir? Asya! sen söyle” (Ö6), “...Enes sence?” (Ö6) gibi ifadelerle çocukların verdiği cevapla ilgili bir yorum açılama yapmadan, cevaptan bağımsız olarak başka bir çocuğa yönelmiştir. (Başka bir çocuğa yönelme ifadeleri) 
Öğretmen adayı çocuklarla beraber kitapların nasıl kullanılması gerektiğini konuşmaktadırlar. Öğretmen adayı çocuklara “kitaplar nasıl kullanmalyyı??” (Ö3) Diye sorar. Çocuklardan biri “ögretmenim temiz kullanmalyyž” (Ç7) diye cevap verir. Öğretmen adayı cevab1 veren çocuğa herhangi bir dönüt vermeden "bugün biચ̨im sinfimı̨a misafir yeni bir geldi. Acaba o misafir nerde?” (Ç19) diye cevaptan bağımsız bir soru yöneltmiştir. (Verilen cevaptan bağımsız soru sorma)

\section{SONUÇ ve TARTIŞMA}

Okul öncesi eğitiminde öğretmen adayları ve çocukların diyaloglarının incelenmesi amacıyla yapılan bu araştırmada elde edilen sonuçlar öğretmen adaylarının diyaloglarda kullandığı soru tipleri, çocukların diyaloglarda kullandığı soru tipleri ve öğretmen adaylarının geri bildirimleri başlıkları altında yorumlanmış ve tartışılmıştır.

\section{Öğretmen Adaylarının Diyaloglarda Kullandığı Soru Tipleri}

Araştırmanın birinci sorusu olan öğretmen adaylarının etkinlik öncesi ve sonrası kullandıkları soru türlerinin dağılımı ile ilgili üç sonuç ortaya çıkmıştır. Birincisi öğretmen adaylarının her iki zaman diliminde de kapalı soruları diğer soru türlerine göre daha fazla kullanmalarıdır. Ortaya çıkan bu sonuç alanyazında yapılan çalışmalarda da görülmektedir (Bayraktar ve Yalçın, 2019; IşıklıŏgluErdoğan ve Akay, 2015; Blatchford ve Mani, 2008). Öğretmen adaylarının diyaloglarda kapalı uçlu soruları daha çok kullanmaları birkaç şekilde yorumlanabilir. İlk olarak öğretmen adaylarının çocuklarla iletişim ve diyaloglarında farklı soru türlerini kullanmaya yönelik bilgi ve deneyim eksikliği böyle bir sonucun ortaya çıkmasına sebep olabilir. Çünkü çocuklarla iletişime geçmek öğretmenlerin ifade ettiği sorunların başında gelmektedir (Seçer, Çeliköz ve Kayılı, 2010). İkincisi kapalı soruların sıklıkla kullanılması okul öncesine devam eden çocuklarının gelişimsel özelliklerinden kaynaklanabilir. Okul öncesi dönem çocuklarının bellekleri daha önce edinilen bilgi ve becerilerin hatırlanarak var olan duruma uyarlanması konusunda yeterli derecede olgunlaşmamış olabilir. Yapılan bir araştırmada da akademik bilgi ve becerilerin hatırlanmasının erken yaşlarda yetersiz olduğu fakat giderek arttığ1 bulunmuştur (Hulme, ve Tordoff, 1989). Üçüncüsü ise öğretmen adaylarının çocukların bilgilerini ortaya çıkarmaya çalışmaları olabilir. Çünkü başarılı diyalogların temelinde önceki bilgilerin dikkate alınması vardır. Bu bağlamda öğretmenler çocukların bilgi düzeylerini ölçmeye yönelik sorulara yoğunlaşabilmektedir (Hasan, Gushendra ve Yonantha, 2018). Araştırmanın birinci sorusunda ortaya çıkan ikinci sonuç etkinlik süreci sonrasında genişletmeye dayalı soru türünün az da olsa artmasıdır. Genişletmeye dayalı sorular var olan bilgilerin ve yaşanılan süreçlerin detaylandırılması ve kavranmasını sağlayan ve neden-sonuç ilişkisini kurmaya yönelik sorulardır (Işıklığlu-Erdoğan ve Akay, 2015). Öğretmenler çocukların 
programdaki kazanımları edinmeleri ve etkinlik sürecini içselleştirmeleri için bu sorulara başvurabilmektedir. Üçüncü sonuç ise öğretmen adaylarının açık uçlu, genişletme ve değerlendirmeye yönelik soruları her iki zamanda da az sormalarıdır. Yapılan araştırmalarda da öğretmenlerin genellikle bilgiye dayalı alt düzey soruları daha çok tercih ettikleri, üst düzey zihinsel aktiviteleri gerektiren soruları ise yeterince kullanmadıkları görülmüştür (Bay ve Sinanoğlu, 2011; Büyükalan, 2002; Blatchford ve Mani, 2008). Fakat bununla beraber araştırmalarda çıkarımsal dil ve soruları kullanmak çocukların kelime dağarcığı ile ilişkili bulunmuştur (Massey, Pence, Justice ve Bowles, 2008; Zucker ve diğerleri, 2010). Bu açıdan okul öncesi öğretmenlerinin çocuklar1 karmaşık, çıkarımsal düzeylerde konuşmaya katılmaya teşvik etmek için neden, nasıl, niçin gibi çocukların üst düzey bilişsel becerilerini geliştirecek soruları kullanması önem taşımaktadır. Bu soru türlerinin kullanılması çocukların bilgiyi sınıfın dışında da kullanabilmeleri için organize etmelerini sağlamaktadır. Bu sorular çocukların daha yetkin olmalarına katkı sağlar. Bu doğrultuda öğretmenler çocukların yaşantıları ve yeni bilgileri bireysel olarak yapılandırması, uygulamaya ve yeni durumlara uyarlanması için çocuklara rehberlik etmeleri gerekmektedir (Darling-Hammond, Flook, CookHarvey, Barron and Osher, 2019).

Öğretmen adaylarının diyaloglarda kullandıkları konuşma araçları ve soru türleri ile ilgili olan araştırmanın ikinci sorusu sonucunda öğretmen adaylarının diyaloglarda en çok araçsız konuşmaları tercih ettiği, bu konuşmaları ise araçlı konuşmaların izlediği görülmüştür. Araçsız konuşmalarda öğretmen adayları soru cevaplarla diyalogu sürdürmüştür. Bu diyaloglarda öğretmen adayları en çok kapalı uçlu en az ise genişletmeye yönelik sorular sormuştur. Araçlı konuşmalarda ise öğretmen adayları sunum, resim, obje ve kuklalardan birbirlerine yakın şekilde faydalanmışlardır. Öğretmen adayları sunum resim ve kuklaları kullandıkları diyaloglarda en çok kapalı uçlu soruları kullanmışken, objeleri tercih ettikleri diyaloglarda ise en çok genişletmeye dayalı sorular sormuştur. Bu bakımdan özellikle konuşmaların somut materyallerle yapılmasının farklı soru türlerine olanak tanıdığı söylenebilir. Bu sonuç aynı zamanda okul öncesi dönem çocuklarının bilişsel gelişimleri ile de yakından ilgilidir. İşlem öncesi dönemde olan bu çocuklar bilgiye daha çok görme, duyma, dokunma gibi duyularını kullanabildikleri somut materyallerle etkileşime girerek ulaşmaktadırlar (Senemoğlu, 1994).

Öğretmen adaylarının soruları genel olarak değerlendirildiğinde konuşma sürecinde daha aktif olduklanı ve bilgiyi ortaya çıkarmaya yönelik sorular sorduklanı bulunmuştur. Bu yaklaşımın ise günümüz okul öncesi eğitim programında etkin olan çocuk merkezli yaklaşım ile yapılandırmacı yaklaşıma uygun olmadığı görülmektedir (Güven, 2019). Yapılandırmacı yaklaşımda öğretmenin rolü çocukları bilgiyle doldurmak veya konuşmaları bilgiye dayalı sözel başanı testleri olarak 
tasarlamaktan öte çocuklara rehberlik ederek onları eleştirel düşünmeye sevk etmek ve bu yönde sorular kullanmaktır (Büyüktaşkapu, Çeliköz ve Akman, 2012). Bununla beraber çocuk merkezli eğitimde önemli olan çocukların ne öğrendiği değil, öğrenme sürecindeki yaşantılarıdır (Santrock, 2018).

\section{Çocukların Diyaloglarda Kullandığı Soru Tipleri}

Çocukların toplam soruları ve bu soruların etkinlik öncesi ve sonrasına göre dağılımına ilişkin araştırmanın üçüncü sorusunda iki sonuç ortaya çıkmıştır. İlk sonuç diyaloglarda çocukların çok az soru sormasıdır. Bu sonuç çocukların gelişim düzeyleri ile uyuşmamaktadır. Beş-altı yaşındaki çocuklar işlem öncesi dönemin ikinci evresinde olup, bilgiye sezgisel olarak yaklaşmaktadırlar. Buna bağlı olarak da neden, nasıl sorularını sıklıkla kullanmaktadırlar (Elkind, 1976). İkinci sonuç ise çocuklarda etkinlik öncesi ve sonrasında öğretmenlerden elde edilen bulgular gibi en çok kapalı soruları tercih etmesidir. Bununla beraber çocuklar her iki zaman diliminde değerlendirmeye yönelik hiç soru sormamışlardır, etkinlik sonrası diyaloglarda da tüm soru türlerinde çocuklar neredeyse hiç soru sormamıştır. Bu veriler öğretmenlerin çocuk odaklı ve sorgulama temelli bir diyalog yaklaşımını benimsemediklerinin göstergesi olabilir.

Çocukların konuşma araçları kullanma durumu ile ilgili olan araştırmanın dördüncü sonucu çocukların en çok sunumlarla yapılan diyaloglarda daha çok soru sorduklarıdır. Çocuklar 36 etkinlik süresince toplam 22 soru sormuş ve bu sorulardan 15’i sunumun kullanıldığı bir etkinlik öncesi diyaloğudur. Bu diyalogda öğretmen adayları günlük yaşamla bağlantılı olan, çocukların merak duygusunu uyandıran ve çocukların soru sormalarına firsat verilen ayakkabının yapım aşamalarının anlatıldığı bir video sunum kullanmıştır. Yapılan araştırmalar da çocukların merakını uyandıran ilginç ve süreç odaklı etkinliklerin çocukların soru sorma becerilerine katkı sağladığını göstermektedir (Clark, Harbaugh ve Seider, 2019a; Clark, Harbaugh ve Seider, 2019b; Spruijt, Ziermans, Dekker ve Swaab,2020). Bu bulgu aynı zamanda öğretmenlerin çocukların meraklarına uygun ve gerçek yaşama odaklı becerilere diyaloglarda daha az yer verdiklerinin de göstergesi olabilir.

\section{Öğretmen Adaylarının Geri Bildirimleri}

Araştırmada ortaya çıkan son sonuç öğretmen adaylarının çocuklara verdiği geri bildirimlerin dağılımı ile ilgilidir. Öğretmen adaylarının çocukların cevaplanına ilişkin geri bildirimleri çoğunlukla çocukların cevabıyla ilişkilidir. Bu durum diyalogların soru cevap-geribildirim formatını doğrulamaktadır (Howe ve Abedin, 2013). Fakat bununla beraber öğretmen adaylarının cevaptan 
bağımsız ifadeleri de azımsanmayacak kadar çoktur. Bu ifadeler sınıf yönetimi, başka çocuğa yönelme ve başka sorulara geçme ile ilgilidir. Tablo yedi genel olarak değerlendirildiğinde öğretmen adaylarının yaklaşık olarak 10 geri bildiriminden birinin sınıf yönetimini sağlama ilgili olduğu görülmektedir. Wragg (1993) tarafindan yapılan çalısmada da öğretmenlerin ifadelerin yarısına yakınının (\%35) sınıf yönetimine yönelik olduğunu bulmuştur. Farklı bir soruya geçmeleri ise sormayı planladıkları soruların hepsini sormak istemeleri, etkinlik sonrasındaki diyaloglarda tüm etkinlik sürecini konuşma ve böylece eğitim müfredatını gerçekleştirme kaygısından olabilir. Bununla beraber sınıfların kalabalık olması da etkili diyalogların oluşmasını engellemiş olabilir. Daha güçlü, yetişkin-çocuk ilişkilerine olanak tanıyan daha küçük öğrenme ortamları katılımı, bağlılığı, başarıyı ve kazanımı geliştirebilir (Darling-Hammond ve diğerleri, 2019; Friedlaender ve diğerleri, 2014). Bu bağlamda etkili eğitim süreçleri için sınıf mevcutlanının en fazla 15-18 olması da önerilmektedir (Mosteller,1995).

\section{Öneriler}

Diyalogun temelini sorular oluşturmaktadır. Diyaloğun bir bileşeni olarak sorular sürecin, yaşantıların anlaşılmasını sağlama, çocukları motive etme veya diyaloğu sürdürmenin bir yolu olarak kullanılabilir. Sorular çocukların motivasyonunu arttırması için ilginç, dikkat çekici olmalı; farklı soru ve cevaplara yönlendirici olmalı ve konuyu derinleştirmek için kısmen bilgilendirici olmalıdır (Goman, 2019). Tüm bu sürecin sağlıklı olması için öğretmenlerin diğer eğitim süreçlerinde yaptıkları gibi diyaloglara da hazırlık yapmaları önerilmektedir. Bu kapsamda öğretmen adayları ve öğretmenlerin diyaloğun niteliğini arttırmak ve sürdürmek için çocukların merak duygusunu geliştirecek ve gerçek yaşamla bağlantılı, ilginç konuşma araçları ve içeriklerine yer vermeleri gerekmektedir.

Çocukların diyalog süresince sordukları soruların az olması öğretmen adayları ve öğretmenlerin genellikle bilinen konuları işlemesi olabilir çünkü çocukların bilmediği ve yaşamla ilişkili olan konularda daha çok soru sordukları görülmüştür (Soydan ve Dereli, 2014). Çocukların soru sorma becerilerinin gelişmesi ve diyalogların çift taraflı etkili olması için özellikle öğretmenlerin günlük etkinliklerini planlarken çocukların ilgi ve ihtiyaçlarını da dikkate alarak onların merak duygusunu geliştirecek etkinliklere ağırlık vermesi önerilmektedir.

$\mathrm{Bu}$ araştırmada öğretmen adaylarının çocuklarla diyalogları toplu oldukları zamanlar dilimlerinden elde edilen verilerle sınırlandırılmıştır. Bu açıdan etkinlik süreçlerinde çocukların öğretmenögretmen adaylarıyla olan diyaloglan incelenebilir. Diyaloglar etkinlik türlerine göre sinıflandırılarak 
da ele alınabilir. Bu araştırmalar etkinliklerin bağlamının ve türünün diyaloglara yansıması hakkında açıklayıcı olabilirler.

Okul öncesine devam eden çocuklanın cinsiyetlerinin ve öğretmenlerin cinsiyetlerinin diyaloğun niteliğinde önemli değişkenler olup olmadığı da ele alınabilir. Cinsiyet değişkenine ek olarak bu çalışmada diyalogların ele alındığı sınıfların birinde serebralpalsili bir çocuk bulunmakla birlikte araştırmanın amacından dolayı bu çocuğa özel olarak odaklanılmamıştır. Diyalog etkileşimlerinde farklı gelişen çocuklar da incelenebilir. Bu incelemeler hem etkili programların oluşturulmasına hem de öğretmenlerin niteliklerin artmasına katkı sağlayabilir.

$\mathrm{Bu}$ araştırma ve buna benzer araştırma sonuçları öğretmen ve öğretmen adayları ile paylaşılarak, sebepleri ve yapılması gerekenler hakkında bireysel ve grup tartısmaları yapılarak konu derinlemesine incelenebilir. Böylece sorunlara çözüm üretmeye yönelik adımlar atılmış olur. Ayrıca öğretmenlere etkili diyalog eğitimleri verilerek mesleki gelişimlerine destek olunabilir. Nitekim Hamre ve arkadaşları (2012) tarafindan öğretmenlere verilen etkileşim temelli eğitimlerin olumlu etkileşime katk1 sağladığı; Bay ve Alisinanoğlu (2012) tarafından öğretmenlere verilen soru eğitim programı sonrasında da öğretmenlerin genişletme ve değerlendirmeye yönelik sorularında artış olduğu görülmüştür.

$\mathrm{Bu}$ araştırmadaki veriler öğretmen adaylarından elde edilmiştir. Öğretmen adayları uygulama süresince ders yürütücülerinden aldıkları dönütler aracıllğıyla kendilerini kişisel ve mesleki olarak geliştirmekte ve öğretmenlik uygulamasını titizlikle yürütmektedirler. Bu bağlamda öğretmen adayları genellikle lisans eğitimleri boyunca gördükleri teorik ve diğer uygulamalı derslerdeki bilgileri burada uygulamaya dönüştürmektedirler (Gündoğdu, Altın, Üstündağ ve Altay, 2018). Buna rağmen öğretmen adaylarının en önemli ihtiyaçları tecrübe eksikliklerinden kaynaklanan çocuklarla iletişim gibi alanlarda görülebilmektedir (Seçer ve diğerleri, 2010). Öğretmen yetiştiren programlarda çocuklarla uygulamalı çalışmalara daha fazla yer verilmesine yönelik müfredat çalışmaları yapılması önerilebilir. Ayrıca başka bir araştırmada öğretmen adaylarının çocuklarla diyalogları, mesleğini yapmakta olan daha tecrübeli öğretmenlerle karşılaştırılabilir.

Veriler ses kayıtlarıyla elde edilmiştir. Genellikle okul öncesi ortamları gürültülü olduğundan (Bulunuz, Ovalı, Çıkrıkçı ve Mutlu, 2017) bu çalışmada veri kayıplarını önlemek adına gerekli önlemler alınmış olmasına rağmen öğretmen ve çocuk konuşmaların anlık not edilmesi ve özellikle video kayıtlarının kullanılması daha özgün verilerin elde edilmesini sağlayabilir. Özellikle video kayıtları çocukların diyalog zamanlarındaki fiziksel hareketlerini, ilgilerini de göstermesi açısından kullanilabilir. 
Son olarak çocukların toplu diyalog zamanları ve bu zamanlarındaki deneyimlerine ilişkin görüşleri alınabilir. Böylece çocuk bakış açısıyla da diyalogların yapısı şekillendirilebilir. Çünkü çocukların ilgi ve ihtiyaçlarının dikkate alındığı uygulamalar daha etkili sonuçlar verebilmektedir.

\section{KAYNAKÇA}

Aytaçlı, B. (2012). Durum çalışmasına ayrıntılı bir bakış. Adnan Menderes Üniversitesi Eğitim Fakültesi Eğitim Bilimleri Dergisi, 3(1), 1-9.

Başkale, H. (2016). Nitel araştırmalarda geçerlik, güvenirlik ve örneklem büyüklüğünün belirlenmesi. Dokuz Eylül Üniversitesi Hemsirelik. Fakültesi Elektronik Dergisi. 9(1), 23-28.

Bay, N. ve Alisinanoğlu, F. (2012). Okul öncesi eğitimi öğretmenlerine uygulanan soru sorma becerisi öğretim programının öğretmenlerin sorularının bilişsel taksonomisine etkisi. Mersin Ë̈itim Fakültesi Dergisi, 3(8),80-93.

Bayraktar, A. ve Yalçın, S. (2019). Examining preservice teachers' questioning and feedback. Journal of Education and Future, (16), 17-28.

Bereiter, C., \& Engelmann, S. (1966). Teaching disadvantaged children in the preschool. Prentice-Hall.

Blatchford, I. \& Mani, L. (2008). Would You Like to Tidy Up Now?' An Analysis of Adult Questioning in the English Foundation Stage. Early Years, 28(1), 5-22.

Bulunuz, M., Ovalı, D. E., Çıkrıłkçı, A. İ., \& Mutlu, E. (2017). Anasınıfinda gürültü düzeyi ve kontrol edilmesine yönelik eğitim uygulamalarının değerlendirilmesi: Eylem araştırması. Eğitim ve Bilim, 42(192).

Büyükalan F., S. (2002). Soru-cevap yöntemine ilişkin ögretimin ögretmenlerin soru sorma düzeyi ve tekniklerine etkisi. Yayımlanmamış Doktora Tezi, Ankara: Gazi Üniversitesi Eğitim Bilimleri Enstitüsü.

Büyüktaşkapu, S., Çeliköz, N. ve Akman, B. (2012). Yapılandırmacı bilim eğitimi programının 6 yaş çocuklarının bilimsel süreç becerilerine etkisi. Eğitim ve Bilim, 37(165).

Calcagni, E., \& Lago, L. (2018). The three domains for dialogue: a framework for analysing dialogic approaches to teaching and learning. Learning, Culture and Social Interaction, 18, 1-12.

Clark, S., Harbaugh, A. G., \& Seider, S. (2019a). Fostering adolescent curiosity through a question brainstorming intervention. Journal of adolescence, 75, 98-112.

Clark, S., Harbaugh, A. G., \& Seider, S. (2019b). Teaching questioning fosters adolescent curiosity: Analyzing impact through multiple-group structural equation modeling. Applied Developmental Science, 1-20.

Coll, C., Rochera, M. J. \& de Gispert, I. (2014). Supporting online collaborative learning in small groups: Teacher feedback on learning content, academic task and social participation. Computers \& Education, 75, 53-64. 
Colwell, M., \& Lindsey, E. (2003). Teacher-child interactions and preschool children's perceptions of self and peers. Early Child Development and Care, 173(2-3), 249-258.

Creswell, J. W. \& Clark, V. L. P. (2007). Designing and conducting mixed methods research. Thousand Oaks, CA:Sage.

Darling-Hammond, L., Flook, L., Cook-Harvey, C., Barron, B., \& Osher, D. (2019). Implications for educational practice of the science of learning and development. Applied Developmental Science, 1-44.

De Vocht, L. (2015). Reconceptualising teacher-child dialogue in early years education as a moral answerability. International Journal of Early Childhood,47(2), 317-330. https://doi.org/10.1007/s13158-015-0140-2.

Downer, J., Sabol, T. J. ve Bridget, H. (2010). Teacher-Child Interactions in the Classroom: Toward a Theory of Within- and Cross-Domain Links to Children's Developmental Outcomes. Early Education and Development. 21(5), 699-723.

Elkind, D. (1976). Child development and education: A Piagetian perspective. New York: Oxford University Press.

Emilson, A., \& Johansson, E. (2009). The desirable toddler in preschool: Values communicated in teacher and child interactions. In Participatory Learning in the Early Years (pp. 77-93). Routledge.

Fletcher, R. (1993). What a writer needs. Portsmouth, NH: Heinemann Friedlaender, D., Burns, D., Lewis-Charp, H., Cook-Harvey, C. M., Zheng, X., \& Darling-Hammond, L. (2014). Student-centered schools: Closing the opportunity gap. Stanford, CA: Stanford Center for Opportunity Policy in Education.

Gillies, R. (2013). Productive academic talk during inquiry-based science. Pedagogies, 8, 126-142. https://doi.org/10.1080/1554480X.2013.767770

Glesne, C. (2013). Nitel araștırmaya giriș (4.baskı). Ankara: Anı Yayıncilık.

Goble, P., \& Pianta, R. C. (2017). Teacher-child interactions in free choice and teacher-directed activity settings: Prediction to school readiness. Early education and development, 28(8), 10351051.

Goman, I. V. (2019, November). Development of the dialogue skills in a foreign language in comparing of oil benchmarks. In Journal of Physics: Conference Series. 1384(1), 12-13,

Graves Jr, Scott. L., \& Howes, C. (2011). Ethnic differences in social-emotional development in preschool: The impact of teacher child relationships and classroom quality. School Psychology Quarterly, 26(3), 202.

Gündoğdu, K., Altın, M., Üstündağ, N. ve Altay, B. (2018). Öğretmen adayları öğretmenlik uygulamasında yeterli mi?(Bir olgubilim çalışması). Adnan Menderes Üniversitesi Sosyal Bilimler Enstitüsü Dergisi, 5(1), 150-166. 
Güven, G. (2019). Okul Öncesi eğitim programının tarihsel gelişim süreci. (Editör Saide Özbey ve Serap Demiriz). Okul Öncesi Eğtimde Programı. İstanbul: Lisans Yayınc1lık.

Hamre, B. K., Pianta, R. C., Burchinal, M., Field, S., LoCasale-Crouch, J., Downer, J. T., ... \& ScottLittle, C. (2012). A course on effective teacher-child interactions: Effects on teacher beliefs, knowledge, and observed practice. American Educational Research Journal, 49(1), 88-123.

Hamre, B., \& Pianta, R. (2001). Early teacher-child relationships and the trajectory of children's school outcomes through eighth grade. Child Development, 72, 625-638. doi: 10.1111/1467-8624.00301.

Hamre, B., Hatfield, B., Pianta, R., \& Jamil, F. (2014). Evidence for general and domain-specific elements of teacher-child interactions: Associations with preschool children's development. Child development, 85(3), 1257-1274.

Hasan, A., Gushendra, R., \& Yonantha, F. (2018). The Influence of Prior Knowledge on Students' Listening and Reading Comprehension. Indonesian Journal of English Education, 4(1), 1-15.

Heller, S. S., Rice, J., Boothe, A., Sidell, M., Vaughn, K., Keyes, A., \& Nagle, G. (2012). Socialemotional development, school readiness, teacher-child interactions, and classroom environment. Early Education \& Development, 23(6), 919-944.

Howe, C., \& Abedin, M. (2013). Classroom dialogue: a systematic review across four decades of research. Cambridge Journal of Education, 43, 325-356. https://doi.org/ 10.1080/0305764X.2013.786024.

Hu, B. Y., Fan, X., Wu, Z., LoCasale-Crouch, J., Yang, N., \& Zhang, J. (2017). Teacher-child interactions and children's cognitive and social skills in Chinese preschool classrooms. Children and Youth Services Review, 79, 78-86.

Hu, B. Y., Wu, H., Curby, T. W., Wu, Z., \& Zhang, X. (2018). Teacher-child interaction quality, attitudes toward reading, and literacy achievement of Chinese preschool children: Mediation and moderation analysis. Learning and Individual Differences, 68, 1-11. https://doi.org/10.1016/j.lindif.2018.09.004.

Hu, B. Y., Zhou, Y., Chen, L., Fan, X., \& Winsler, A. (2017). Preschool expenditures and Chinese children's academic performance: The mediating effect of teacher-child interaction quality. Early Childhood Research Quarterly, 41, 37-49. http://dx.doi.org/10.1016/j.ecresq.2017.05.002.

Hulme, C., \& Tordoff, V. (1989). Working memory development: The effects of speech rate, word length, and acoustic similarity on serial recall. Journal of Experimental Child Psychology, 47(1), $72-87$.

Işıklığlu-Erdoğan, N. ve Akay, B. (2015). Okul Öncesi Eğitimde Hikâye Okuma ve Öğretmen Sorularının İncelenmesi. Mehmet Akif Ersoy Üniversitesi Eğitim Fakültesi Dergisi. 1(36), 34-46.

Lefstein, A., Snell, J., \& Israeli, M. (2015). From moves to sequences: Expanding the unit of analysis in the study of classroom discourse. British Educational Research Journal, 41(5), 866-885. 
Lippard, C. N., La Paro, K. M., Rouse, H. L., \& Crosby, D. A. (2018, February). A closer look at teacher-child relationships and classroom emotional context in preschool. In Child \& Youth Care Forum, 47(1), 1-21.

Mahfoodh, O. H. A. (2017). “I feel disappointed”: EFL university students' emotional responses towards teacher written feedback. Assessing Writing, 31, 53-72.

Massey, S.L.,Pence, K.L., Justice, L.M. \& Bowles, R.P. (2008). Educators' use of cognitively challenging questions in economically disadvantaged preschool classroom contexts. Early Education and Development, 19(2), 340-360.

Miles, M.B., \& Huberman, A.M. (1994). Qualitative data analysis. California: SAGE Publications Inc.

Moritz-Rudasill, K., Rimm-Kaufman, S. E., Justice, L. M., \& Pence, K. (2006). Temperament and language skills as predictors of teacher-child relationship quality in preschool. Early Education and Development, 17(2), 271-291.

Mosteller, F. (1995). The Tennessee study of class size in the early school grades. The Future of Children, 5(2), 113-127.

Muhonen, H., Pakarinen, E., Lerkkanen, M. K., Barza, L., \& Von Suchodoletz, A. (2018). Patterns of dialogic teaching in kindergarten classrooms of Finland and the United Arab Emirates. Learning, Culture and Social Interaction. https://doi.org/10.1016/j.lcsi.2018.11.011.

Özen, Y. ve Gül, A (2007). Sosyal ve eğitim bilimleri araştırmalarında evren-örneklem sorunu. Atatürk Üniversitesi Kąım Karabekir Eğitim Fakültesi Dergisi, 15, 394-422.

Pianta, R. C., Howes, C., Burchinal, M., Bryant, D., Clifford, R., Early, C., et al.(2005). Features of pre-kindergarten programs, classrooms, and teachers: Do they predict observed classroom quality and child-teacher interactions? Applied Developmental Science, 9, 144-159. http://dx.doi.org/10.1207/s1532480xads0903.

Quinton, S. ve Smallbone, T. (2010). Feeding forward: Using feedback to promote student reflection and learning-A teaching model. Innovations in Education and Teaching International, 47(1), 125-135.

Santrock, J. W. (2018). Yaşam boyu gelişim. Ankara: Nobel

Santrock, J. (2010). Lifespan development (13. Baskı). America: McGraw-Hill

Seçer, Z., Çeliköz, N. ve Kayllı, G. (2010). Okul öncesi öğretmenliği okul uygulamalarında yaşanan sorunlar ve çözüm önerileri (ss. 128-152). Yüəüncü Yul Üniversitesi Eğitim Fakültesi Dergisi, $7(1), 128-152$.

Seifert, K. (1969). Comparison of verbal interaction in two preschool programs. Young Children, 24(6), 350-355.

Senemoğlu, N. (1994). Okulöncesi eğitim programı hangi yeterlikleri kazandırmalıdır?. Hacettepe Üniversitesi Ë̈itim Fakültesi Dergisi, 10, 21-30. 
Sohmer, R., Michaels, S., \& O'Connor, M. C. ve Resnick, L. (2009). Guided construction of knowledge in the classroom: The troika of talk, tasks and tools. In B. Schwarz, T. Dreyfus, ve R. Herhkowitz (Eds.). Transformation of knowledge through classroom interaction (pp. 105-129). London:Routledge.

Soydan, S. B. ve Dereli, H. M. (2014). Farklı yaklaşımları uygulayan okul öncesi öğretmenlerinin çocuklarda düşünme becerilerini geliştirmek için kullandıkları stratejilerin incelenmesi. Kastamonu Eğitim Dergisi, 22(2), 475-496.

Spruijt, A. M., Ziermans, T. B., Dekker, M. C., \& Swaab, H. (2020). Educating parents to enhance children's reasoning abilities: A focus on questioning style. Journal of Applied Developmental Psychology, 66, 101102.

Tashakkori, A., \& Creswell, J. W. (2007). The new era of mixed methods. Journal of Mixed Methods Research, 11(1), 3-7.

Trawick-Smith, J., Swaminathan, S., \& Liu, X. (2016). The relationship of teacher-child play interactions to mathematics learning in preschool. Early Child Development and Care, 186(5), 716-733.

Van Craeyevelt, S., Verschueren, K., Vancraeyveldt, C., Wouters, S., \& Colpin, H. (2017). The role of preschool teacher-child interactions in academic adjustment: An intervention study with Playing-2-gether. British Journal of Educational Psychology, 87(3), 345-364.

Wang, C., Hatzigianni, M., Shahaeian, A., Murray, E., \& Harrison, L. J. (2016). The combined effects of teacher-child and peer relationships on children's social-emotional adjustment. Journal of school psychology, 59, 1-11.

Wang, M. T., Brinkworth, M., \& Eccles, J. (2013). Moderating effects of teacher-student relationship in adolescent trajectories of emotional and behavioral adjustment. Developmental psychology, 49(4), 690.

Warren-Leubecker, A. \& Bohannon, J. N. (1983). The effects of verbal feedback and listener type on the speech of preschool children. Journal of Experimental Child Psychology, 35(3), 540-548.

Webb, N. M., Franke, M. L., De, T., Chan, A. G., Freund, D., Shein, P., \& Melkonia, D. (2009). "Explain to your partner": Teachers' instructional practices and students' dialogue in small groups. Cambridge Journal of Education, 39(1), 49-70. https://doi.org/10.1080/03057640802701986.

Whittaker, J. E., Williford, A. P., Carter, L. M., Vitiello, V. E., \& Hatfield, B. E. (2018). Using a standardized task to assess the quality of teacher-child dyadic interactions in preschool. Early Education and Development, 29(2), 266-287. https://doi.org/10.1080/10409289.2017.1387960.

Williford, A. P., LoCasale-Crouch, J., Whittaker, J. V., DeCoster, J., Hartz, K. A., Carter, L. M., ... \& Hatfield, B. E. (2017). Changing teacher-child dyadic interactions to improve preschool children's externalizing behaviors. Child development, 88(5), 1544-1553.

Wragg, E.C. (1993). Primary Teaching Skills. London and New York: Routledge. 
Yıldırım, A. ve Şimşek, H. (2013). Sosyal Bilimlerde Nitel Araştırma Yöntemleri. (9. Baskı). Ankara: Seçkin Yayıncllık.

Yıldız, R., Demiriz, S. ve Ulutaş, İ. (2018). STEAM Projelerinin Okul Öncesi Dönem Çocuklarının Öğrenme İlgilerine Etkisi. Presented at the 17. Uluslararası Simf Öğretmenliği Sempozyumu. Başlama tarihi:11.04.2018 Bitiş tarihi:14.04.2018

Zucker, T. A., Justice, L. M., Piasta, S. B., \& Kaderavek, J. N. (2010). Preschool teachers' literal and inferential questions and children's responses during whole-class shared reading. Early Childhood Research Quarterly, 25(1), 65-83. 